\title{
Temporal patterns of larval fish distribution and abundance in a coastal area of northern Greece*
}

\author{
EMMANUIL T. KOUTRAKIS, ARGYRIS A. KALLIANIOTIS and \\ ATHANASSIOS C. TSIKLIRAS \\ Fisheries Research Institute-National Agricultural Research Foundation, Nea Peramos, 640 07, Kavala, Greece. \\ E-mail: koutrman@otenet.gr
}

\begin{abstract}
SUMMARY: Species composition, abundance and diversity of fish larvae were assessed in the Strymonikos and Ierissos Gulfs (northern Aegean Sea, Greece). Both gulfs are affected by the freshwater input of the Rivers Strymon and Rihios; water depth does not exceed $80 \mathrm{~m}$. Samples were collected using a bongo net sampler $(250 \mu \mathrm{m}$ mesh size $)$ over a grid of 35 stations in six cruises between June 1997 and May 1998. A total of 48 taxa of fish larvae (36 species, 5 genera and 7 families) were identified. The majority of identified fish larvae taxa consisted of demersal species that included larvae of Bothidae, Gobiidae, Callionymidae, Sparidae and Serranidae. The highest number of species occurred in the warm season (May, June, July, September) and this was attributed to the summer spawners that start their reproduction period during spring/early summer. The European anchovy (Engraulis encrasicolus) was the dominant species between July and September, and the European sardine (Sardina pilchardus) between November and March. Two distinct seasons (warm and cold) were identified by multivariate analysis, highlighting the importance of seasonality in shaping the community structure. The absence of well-defined larval fish associations revealed the importance of depth in the identification of different spatial patterns in an area.
\end{abstract}

Key words: seasonal patterns, abundance, diversity, fish larvae, Greece.

RESUMEN: PATRONES TEMPORALES EN LA DISTRIBUCIÓN Y ABUNDANCIA DE LARVAS DE PECES EN UN ÁREA COSTERA DEL NORTE DE GRECIA. - Se evaluaron la composición, abundancia y diversidad de las larvas de peces en los golfos de Strymonikos y Ierissos (norte del mar Egeo, Grecia). Ambos golfos están afectados por la llegada de agua dulce de los ríos Strymon y Rihios y, en ellos, la profundidad no supera los $80 \mathrm{~m}$. Las muestras se recolectaron en seis campañas realizadas entre los meses de junio de 1997 y mayo de 1998, sobre una parrilla de 35 estaciones, utilizando una red Bongo (con malla de 250 $\mu \mathrm{m})$. Entre las larvas de peces se identificó un total de 48 taxa (36 especies, 5 géneros y 7 familias). La mayoría de las larvas identificadas correspondieron a especies demersales de las familias Bothidae, Gobiidae, Callionymidae, Sparidae y Serranidae. El número más alto de especies apareció durante la estación cálida (mayo, junio, julio y septiembre) y esto se atribuyó a los ponedores de verano que inician su periodo de reproducción en primavera/principio de verano. La anchoa europea (Engraulis encrasicolus) fue la especie dominante de julio a septiembre, y la sardina europea (Sardina pilchardus) de noviembre a marzo. Mediante análisis multivariante se identificaron dos estaciones distintas (cálida y fría), destacando la importancia de la estacionalidad en la estructuración de la comunidad. La ausencia de asociaciones de larvas bien definidas reveló la importancia de la profundidad en la identificación de diferentes patrones espaciales en el área.

Palabras clave: patrones estacionales, abundancia, diversidad, larvas de peces, Grecia.

\section{INTRODUCTION}

Ichthyoplankton research plays a key role in our understanding of the ecology and evolution of fish

*Received May 22, 2003. Accepted November 24, 2003. faunas and their constituent populations (Moser and Smith, 1993). Research into the distribution and abundance of ichthyoplankton is likely to improve our understanding of the interrelationships between fish species during their early life stages, as well as an understanding of adult spawning patterns (Nona- 
ka et al., 2000). Changes in the patterns of distribution and abundance of larvae reflect changes in both the distributional range of the adult fish and features of their reproductive strategies such as timing, duration and location of spawning (Doyle et al., 1993). The relationship between spatial and temporal distribution of ichthyoplankton in relation to geographic and oceanographic conditions is important from the ecological and economic perspectives.

In the past, extensive work on larval fish assemblages has been carried out in the Central Pacific, Indo-Pacific, Antarctic, South Atlantic, Western North Atlantic and North Pacific (e.g. Moser and Smith, 1993). In the Mediterranean, larval fish assemblage studies have been carried out in the northwestern Mediterranean (Sabatés, 1990; Palomera and Olivar, 1996; Sabatés and Olivar, 1996; Olivar and Sabatés, 1997), paying particular attention to commercial small pelagic fish larvae (Palomera 1992; Palomera and Sabatés, 1990; Garcia and Palomera, 1996). Ichthyoplankton data on the eastern Mediterranean, especially on a seasonal basis, are limited. Larval fish surveys have been conducted in northern (Somarakis et al., 2000; Somarakis et al., 2002), central (Ganias et al., 2000; Caragitsou et al., 2001), western (Sorra et al., 2000), and southern (Papasissi, 1998) Greek waters. No information is available on the seasonal distribution of larval fish in the Strymonikos and Ierissos Gulfs, which are important fishing grounds for anchovy and sardine, the most important pelagic fish in terms of biomass in the Thracian Sea (Kallianiotis, 1996). The aim of this study was to determine the seasonal taxonomic composition of the larvae in the Strymonikos and Ierissos Gulfs and to describe the overall seasonal pattern in their abundance.

\section{MATERIALS AND METHODS}

\section{Study site}

Strymonikos and Ierissos Gulfs are located at the central part of the northern Aegean Sea occupying a total area of $6.3 \times 10^{8} \mathrm{~m}^{2}$ (Fig. 1). Strymonikos (area of $5.2 \times 10^{8} \mathrm{~m}^{2}$ ) and Ierissos Gulfs (area of $1.1 \times 10^{8}$ $\mathrm{m}^{2}$ ) have a coastline of $70 \mathrm{~km}$. Water depth does not exceed $80 \mathrm{~m}$. Both gulfs are affected by freshwater input from the Rivers Strymon and Rihios, which are the main sources of nutrients and pollutants (domestic and agricultural) into the sea (Stamatis et al., 2001). Hydrology in the area is also influenced

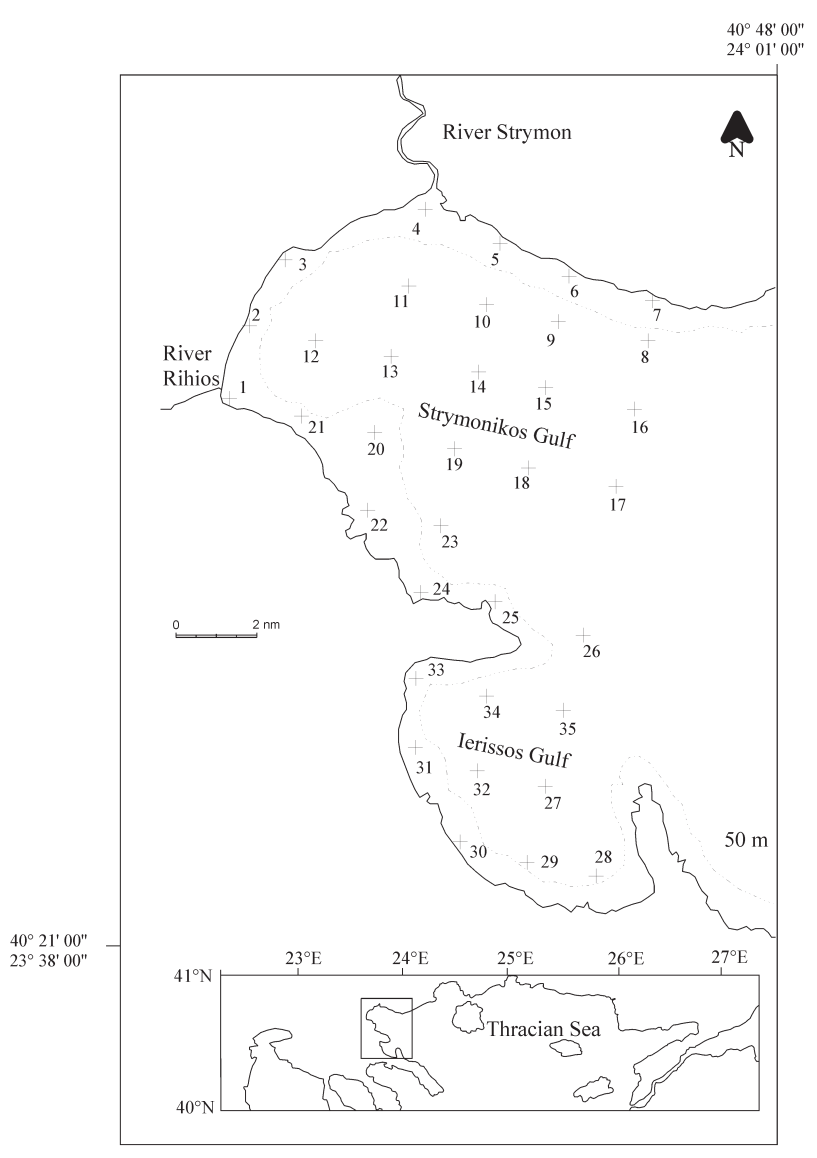

FIG. 1. - Map of Strymonikos and Ierissos Gulfs with the grid of the 35 sampling stations.

by the inflow of cooler and fresher Black Sea Water, which is seasonally variable (Kaloumenos, 1984; Barbopoulos et al., 2000). Black Sea Water forms a strong surface current flowing through the Dardanelles with an average speed of approximately 0.60 $\mathrm{m} \mathrm{s}^{-1}$, moving cyclonically along the Thracian Sea (Bethoux, 1980; Malanotte-Rizzoli and Hecht, 1988). Surface water mass properties of the Strymonikos Gulf are also affected by buoyant water discharge at the vicinity of the Strymon River and Rihios River estuaries. The discharge pattern of the Strymon River shows great seasonal variability, ranging from $18 \mathrm{~m}^{3} \mathrm{~s}^{-1}$ in August to $122 \mathrm{~m}^{3} \mathrm{~s}^{-1}$ in April (Mertzanis, 1994). The River Rihios with a mean annual discharge of $0.90 \mathrm{~m}^{3} \mathrm{~s}^{-1}$, which is relatively constant throughout the year, flows to the western part of this coastal area. Also, a number of seasonal streams and torrents outflow in the Strymonikos Gulf, having a total mean annual flow of $1.70 \mathrm{~m}^{3} \mathrm{~s}^{-1}$ (Hatzigiannakis, 1999).

The water column was generally well stratified during the present study and the thermocline was located at a depth of 15-25 $\mathrm{m}$ in June and September 
(Sylaios et al., 2003). Sea surface temperature ranged from $10.88^{\circ} \mathrm{C}$ in February 1998 to $22.57^{\circ} \mathrm{C}$ in September 1997. Sea surface salinity ranged from 32.71 in September 1997 to 34.1 in November 1997. Freshwater volume in the Strymonikos Gulf ranged from $12.6 \cdot 10^{6} \mathrm{~m}^{3}$ in September 1997 to $65.8 \cdot 10^{6} \mathrm{~m}^{3}$ in February 1998 (Sylaios et al., 2003). The coastal circulation of the Strymonikos Gulf is rich in mesoscale and smaller-scale features, including meanders, convergences, divergences and intrusion zones of lowsalinity surface water originating from the Rivers Strymon and Rihios (Sylaios et al., 2003). Geostrophic circulation of the surface layer (5-40 m) at the outer Strymonikos Gulf clearly shows a frontal system with a north-south direction and a southward flow into Ierissos Gulf during the summer. During the rest of the year a frontal zone develops at the outer boundary (September) and an anti-cyclonic eddy moves water out of the Strymonikos Gulf (November, February) (Sylaios et al., 2003).

\section{Sampling procedure}

Samples were collected in June, July, September and November 1997, and March and May 1998. A grid consisting of 35 stations over seven transects perpendicular to the western coast of the Strymonikos and Ierissos Gulfs was sampled at each sampling period. The distance between stations was $c a .4 \mathrm{~km}$ and the depths varied between 13 and $78 \mathrm{~m}$ (Fig. 1). A bongo net sampler (Bongo-Net 20), which consists of a standard $20 \mathrm{~cm}$ diameter bongo frame fitted with $250 \mu \mathrm{m}$ mesh nets, was used. A flowmeter was fitted at the mouth of each net for the estimation of the volume of water filtered. Most stations were positive, i.e. at least one larva was captured. Tows were oblique, from within $5 \mathrm{~m}$ of the bottom to the surface for all stations. Retrieval speed was $10-20 \mathrm{~m} / \mathrm{min}$. The samples were fixed in $4 \%$ formaldehyde solution in seawater and then the fish larvae were sorted and identified to the lowest possible taxonomic level using a stereoscopic microscope in the laboratory. The focus in the present study was on larvae rather than total ichthyoplankton, since fish eggs are still poorly known and incompletely identified in most ichthyoplankton collections. The number of fish larvae collected at each station was standardised to the number beneath a unit of sea surface area $\left(10 \mathrm{~m}^{2}\right)$ using the equation of Nonaka et al. (2000):

$$
Y_{i}=\frac{\left(10 \times d_{i} \times x_{i}\right)}{v_{i}}
$$

where $Y_{i}$ is the number of larvae of each species under $10 \mathrm{~m}^{2}$ of sea surface at station $i, x_{i}$ is the number of larvae taken at station $i, v_{i}$ is the volume of water filtered in $\mathrm{m}^{3}$, and $d_{i}$ is the maximum depth of haul $i$.

\section{Data analysis}

The monthly abundance of the larvae of each species was the mean of the standardised number of larvae at all positive stations for individual species. The Shannon-Wiener $\left(\mathrm{H}^{\prime}\right)$ and Simpson $\left(\mathrm{D}^{\prime}\right)$ indices of diversity were used (Krebs, 1994), along with Pielou's evenness $\left(\mathrm{J}^{\prime}\right)$ index (Magurran, 1988). Species richness was calculated as Margalef's index (d), which also incorporates the total number of individuals (Clarke and Warwick, 1994). The monthly means of each index were tested for differences between months using analysis of variance (ANOVA) and Fisher's least significant difference (LSD) tests (Zar, 1999). Multivariate analyses were performed to study possible larval fish assemblages in the study area, following the procedures outlined by Clarke and Warwick (1994). The Primer programme was used for the multivariate analyses (Clarke and Gorley, 2001). Prior to analysis, the data were transformed using the $\log (\mathrm{x}+1)$ function to reduce the influence of large values. An effort was made to distinguish patterns between the cold (November, March) and the warm (May, June, July, September) season and within each season and each month, and spatial patterns such as depth zones (within and beyond the $50 \mathrm{~m}$ contour), distance from the river mouth, and separately for the Strymonikos and Ierissos Gulfs. Taxa that were present at less than $10 \%$ of the stations at each sampling were removed from the analysis. Similarity matrices based on the Bray-Curtis similarity measure were generated, after which non-metric multidimensional scaling (MDS) was used to graphically display a two-dimensional plot of the inter-relationships between samples based on the relative abundance (number of larvae $/ 10 \mathrm{~m}^{2}$ ) of each taxonomic group. Samples in plots that were close together were most similar and the extent to which plots displayed the relationships between samples (i.e. goodness of fit) was determined by a stress coefficient. Stress coefficients $<0.1$ indicate a good portrayal of data with no real prospect of misleading interpretation (Clarke and Warwick, 1994). Analyses of similarities (ANOSIM) identified whether differences in assemblage groupings (in depth zones and sampling peri- 
TABLE 1. - List of the taxa and their taxonomic authority (Froese and Pauly, 2003) collected in Strymonikos (S) and Ierissos (I) Gulfs between June 1997 and May 1998 showing the mean abundance $\left(\mathrm{N}\right.$, larvae/10 $\left.\mathrm{m}^{2}\right)$, and the percentage of samples in which species occurred.

\begin{tabular}{|c|c|c|c|c|c|c|c|c|c|c|c|c|c|}
\hline \multirow[t]{2}{*}{ Family } & \multirow[t]{2}{*}{ Gulf } & \multicolumn{2}{|c|}{ Jun 97} & \multicolumn{2}{|c|}{ Jul 97} & \multicolumn{2}{|c|}{ Sep 97} & \multicolumn{2}{|c|}{ Nov 97} & \multicolumn{2}{|c|}{ Mar 98} & \multicolumn{2}{|c|}{ May 98} \\
\hline & & $\mathrm{N}$ & $\%$ & & $\%$ & $\mathrm{~N}$ & $\%$ & $\mathrm{~N}$ & $\%$ & $\mathrm{~N}$ & $\%$ & & $\%$ \\
\hline Ammodytidae & & & & & & & & & & & & & \\
\hline Gymnammodytes cicerelus (Rafinesque, 1810) & $\mathrm{S}, \mathrm{I}$ & & & & & & & & & 74 & 11 & & \\
\hline $\begin{array}{l}\text { Apogonidae } \\
\text { Apogon imberbis (Linnaeus 1758) }\end{array}$ & & & & & & & & & & & & & \\
\hline $\begin{array}{l}\text { Apogon imberbis (Linnaeus, 1758) } \\
\text { Blennidae }\end{array}$ & $\mathrm{S}$ & & & & & 45 & 3 & & & & & & \\
\hline Blennidae & $\mathrm{S}, \mathrm{I}$ & 30 & 3 & & & 73 & 3 & & & & & 20 & 3 \\
\hline Blennius ocellaris Linnaeus, 1758 & $\mathrm{~S}$ & 35 & 3 & & & & & & & & & & \\
\hline Parablennius gattorugine (Linnaeus, 1758) & $\mathrm{S}, \mathrm{I}$ & 31 & 3 & 75 & 3 & 64 & 3 & & & & & 27 & 6 \\
\hline Bothidae & & & & & & & & & & & & & \\
\hline Arnoglossus laterna (Walbaum, 1792) & $\mathrm{S}, \mathrm{I}$ & 36 & 3 & & & 121 & 6 & & & & & & \\
\hline Arnoglossus thori Kyle, 1913 & S, I & 58 & 46 & 115 & 20 & 126 & 37 & 31 & 9 & 30 & 9 & 28 & 6 \\
\hline $\begin{array}{l}\text { Callionymidae } \\
\text { Callionvmus spp. }\end{array}$ & & & & & & & & & & & & & \\
\hline $\begin{array}{l}\text { Callionymus spp. } \\
\text { Carangidae }\end{array}$ & S, I & 83 & 54 & 88 & 17 & 90 & 23 & & & 21 & 6 & 54 & 71 \\
\hline Trachurus mediterraneus (Steindachner, 1868) & S, I & 35 & 11 & 144 & 9 & 133 & 17 & & & & & & \\
\hline Centracanthidae & $\mathrm{S}$ & 33 & 3 & 180 & 3 & 188 & 3 & & & & & & \\
\hline $\begin{array}{l}\text { Cepolidae } \\
\text { Cenola macronhthalma (Linnaeus 1758) }\end{array}$ & & & & & & & & & & & & & \\
\hline $\begin{array}{l}\text { Cepola macrophthalma (Linnaeus, 1758) } \\
\text { Clupeidae }\end{array}$ & $\mathrm{S}$ & 44 & 14 & & & 115 & 14 & & & & & & \\
\hline Sardina pilchardus (Walbaum, 1792) & $\mathrm{S}, \mathrm{I}$ & & & & & & & 187 & 20 & 50 & 17 & & \\
\hline Sardinella aurita Valenciennes, 1847 & $\mathrm{~S}$ & & & 97 & 3 & 98 & 3 & & & & & & \\
\hline Cynoglossidae & & & & & & & & & & & & & \\
\hline $\begin{array}{l}\text { Symphurus nigrescens Rafinesque, } 1810 \\
\text { Engraulidae }\end{array}$ & $\mathrm{S}, \mathrm{I}$ & & & & & 159 & 20 & & & & & & \\
\hline Engraulis encrasicolus (Linnaeus, 1758) & S, I & 790 & 91 & 864 & 74 & 2602 & 91 & 49 & 3 & & & 1525 & 91 \\
\hline Gadidae & & & & & & & & & & & & & \\
\hline Gadiculus argenteus argenteus Guichenot, 1850 & I & & & & & & & & & 23 & 3 & & \\
\hline Gadidae & I & & & & & & & 42 & 3 & & & & \\
\hline Gaidropsarus spp. & $\mathrm{S}, \mathrm{I}$ & & & & & & & & & 23 & 9 & & \\
\hline Gobiidae & & & & & & & & & & & & & \\
\hline Crystallogobius linearis (Von Düben, 1845) & I & & & & & & & & & & & 18 & 3 \\
\hline Gobius niger Linnaeus, 1758 & $\mathrm{~S}, \mathrm{I}$ & 62 & 23 & & & 189 & 14 & & & & & 27 & 26 \\
\hline Gobiidae & $\mathrm{S}, \mathrm{I}$ & 49 & 17 & 72 & 6 & 147 & 20 & 22 & 6 & 66 & 29 & 22 & 11 \\
\hline Labridae & & & & & & & & & & & & & \\
\hline Coris julis (Linnaeus, 1758) & S, I & 40 & 17 & & & & & & & & & & \\
\hline Labridae & S, I & 36 & 20 & & & & & & & & & 29 & 43 \\
\hline Mugilidae & S, I & & & & & 87 & 11 & 57 & 6 & & & 31 & 3 \\
\hline Mullidae & & & & & & & & & & & & & \\
\hline Mullus spp. & $\mathrm{S}, \mathrm{I}$ & 17 & 6 & 200 & 3 & 165 & 3 & & & & & 12 & 3 \\
\hline Myctophidae & & & & & & & & & & & & & \\
\hline Ceratoscopelus maderensis (Lowe, 1839) & $\mathrm{S}$ & 24 & 3 & & & & & 105 & 3 & & & & \\
\hline Diaphus holti Taning, 1918 & $\mathrm{~S}, \mathrm{I}$ & 51 & 9 & & & & & & & & & & \\
\hline Hygорһит spp. & $\mathrm{S}, \mathrm{I}$ & & & & & & & 19 & 3 & 91 & 11 & 19 & 3 \\
\hline Lampanyctus crocodilus (Risso, 1810) & $\mathrm{S}, \mathrm{I}$ & 35 & 3 & & & & & & & 25 & 6 & & \\
\hline Ophidiidae & & & & & & & & & & & & & \\
\hline Parophidion vassali (Risso, 1810) & $\mathrm{S}$ & & & & & 91 & 3 & & & & & & \\
\hline Pomacentridae & & & & & & & & & & & & & \\
\hline $\begin{array}{l}\text { Chromis chromis (Linnaeus, 1758) } \\
\text { Scombridae }\end{array}$ & $\mathrm{S}, \mathrm{I}$ & & & 108 & 11 & 91 & 20 & & & & & & \\
\hline $\begin{array}{l}\text { Scombridae } \\
\quad \text { Auxis rochei rochei (Risso, 1810) }\end{array}$ & & & & 270 & 2 & 225 & 3 & & & & & & \\
\hline Scomber japonicus Houttuyn, 1782 & $\mathrm{~S}, \mathrm{I}$ & 30 & 3 & 98 & 9 & 127 & 9 & & & & & & 3 \\
\hline Scorpaenidae & & & & & & & & & & & & & \\
\hline Scorpaena spp. & $\mathrm{S}, \mathrm{I}$ & & & & & 97 & 14 & & & & & & \\
\hline Serranidae & & & & & & & & & & & & & \\
\hline Anthias anthias (Linnaeus, 1758) & S & 71 & 3 & & & & & & & & & & \\
\hline Callanthias ruber (Rafinesque, 1810) & $\mathrm{S}$ & 48 & 3 & & & & & & & & & & \\
\hline Serranus cabrilla (Linnaeus, 1758) & $\mathrm{S}, \mathrm{I}$ & 87 & 11 & 90 & 3 & 118 & 9 & & & & & 17 & 6 \\
\hline Serranus hepatus (Linnaeus, 1758) & $\mathrm{S}, \mathrm{I}$ & 58 & 34 & 118 & 20 & 131 & 43 & & & & & 51 & 20 \\
\hline Soleidae & & & & & & & & & & & & & \\
\hline Microchirus variegatus (Donovan, 1808) & $\mathrm{S}$ & & & & & & & & & & & 19 & 3 \\
\hline Sparidae & & & & & & & & & & & & & \\
\hline Diplodus sargus sargus (Linnaeus, 1758) & $\mathrm{S}$ & 48 & 3 & & & & & & & & & & \\
\hline Lithognathus mormyrus (Linnaeus, 1758) & $\mathrm{S}$ & & & 220 & 3 & 150 & 3 & & & & & & \\
\hline Pagellus acarne (Risso, 1827) & I & & & & & & & 122 & 3 & & & & \\
\hline Pagrus pagrus (Linnaeus, 1758) & $\mathrm{S}$ & & & & & 81 & 3 & & & & & 31 & 3 \\
\hline Sparidae & S, I & 62 & 37 & 104 & 9 & 82 & 14 & 21 & 3 & & & 18 & 3 \\
\hline Sternoptycidae & & & & & & & & & & & & & \\
\hline Maurolicus muelleri (Gmelin, 1789) & $\mathrm{S}, \mathrm{I}$ & 55 & 6 & & & & & & & & & & \\
\hline Synodontidae & & & & & & & & & & & & & \\
\hline $\begin{array}{l}\text { Synodus saurus (Linnaeus, 1758) } \\
\text { Trachinidae }\end{array}$ & $\mathrm{S}$ & 48 & 3 & 73 & 3 & 141 & 3 & & & & & & \\
\hline $\begin{array}{l}\text { Irachinidae } \\
\text { Trachinus draco Linnaeus, } 1758\end{array}$ & $\mathrm{~S}$ & & & & & 30 & 3 & & & & & & \\
\hline
\end{tabular}


ods) in the MDS ordinations were significant. The values of $\mathrm{R}$ statistic are an absolute measure of how well separated the groups are and range between 0 (indistinguishable) and 1 (well separated) (Clarke and Gorley, 2001). Similarity percentage analyses (SIMPER) were used to determine the dominant taxa in each seasonal grouping.

\section{RESULTS}

The larval ichthyofauna collected throughout the study period consisted of 48 taxa representing 27 families. Forty-four taxa were caught in Strymonikos Gulf and 31 in Ierissos (Table 1). In total, 5290 fish larvae were collected, 5104 of which were identified. Overall, the larvae of European anchovy, Engraulis encrasicolus, were dominant in both gulfs, followed by a limited number of larvae representing the families Callionymidae, Serranidae, Bothidae and Mugilidae. As determined by SIMPER, the European anchovy contributed to the community mostly in June, July, September and May with a percentage dominance ranging between 87.70
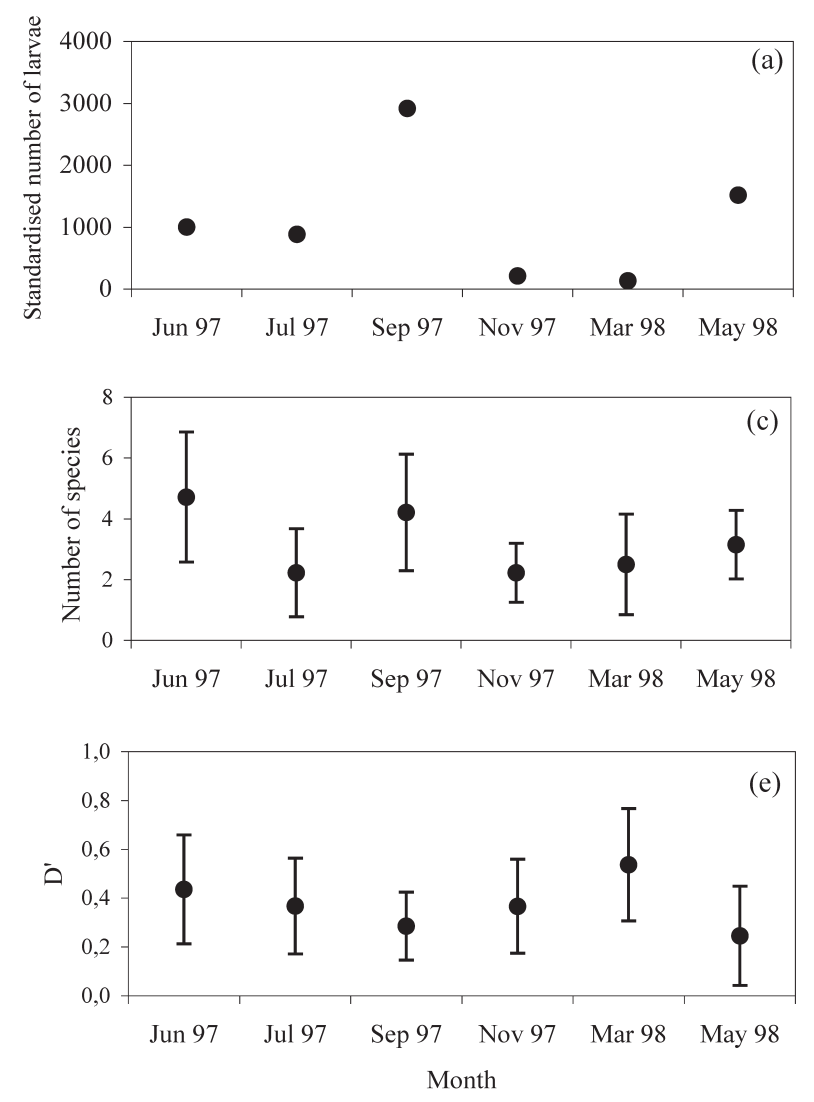

and $97.72 \%$. The European sardine, Sardina pilchardus, contributed mostly in November (93.11\%), while Gobiidae contributed mostly in March (74.21\%), followed by the European sardine (11.93\%).

In general, the mean standardised number of individuals differed significantly between the months $(\mathrm{F}=9.75, \mathrm{P}<0.05)$ and was significantly higher in September than in all other months (Fig. 2a). Mean species richness differed significantly between months $(\mathrm{F}=7.79, \mathrm{P}<0.05)$ and was higher in June (Fisher's LSD, P<0.05) (Fig. 2b). The number of taxa also varied significantly between the months $(\mathrm{F}=10.51, \mathrm{P}<0.05)$ and was higher in June and September than in all other months, but no difference was observed between June and September (Fisher's LSD, $\mathrm{P}<0.05$ ) (Fig. 2c). The means of the two indices of diversity differed significantly between months (Simpsons: F=7.08, $\mathrm{P}<0.05$; ShannonWiener: $F=5.47, \mathrm{P}<0.05)$. The application of Fisher's LSD test indicated that taxa diversity was significantly $(\mathrm{P}<0.05)$ higher in March (Figs. 2d, 2e). Mean evenness differed significantly between months $(\mathrm{F}=10.96, \mathrm{P}<0.05)$ and was higher in March, Novem-
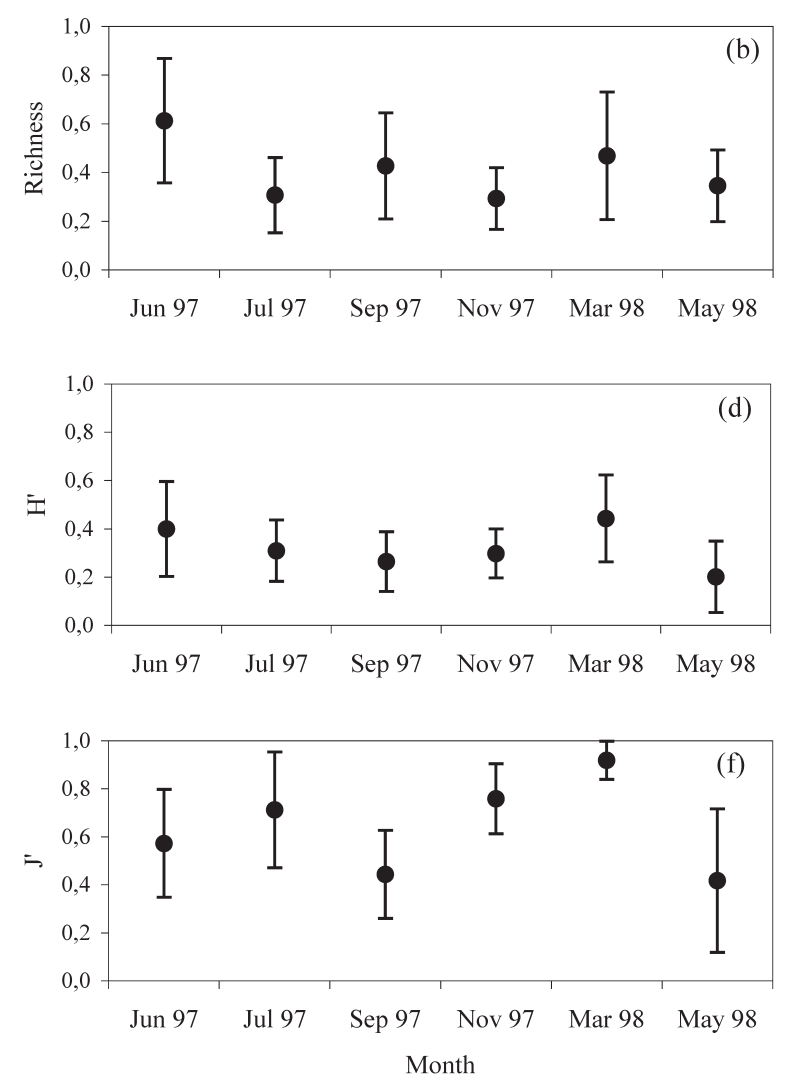

FIG. 2. - Mean standardised number of larvae (a), mean species richness (b), mean number of taxa (c) and the mean Shannon-Wiener (d), Simpson (e) indices of diversity, along with Pielou's index of evenness (f), per sampling period for Strymonikos Gulf. The error bars indicate \pm standard deviations. 
ber and July than in all other months (Fig. 2f).

The majority of identified fish larvae taxa consisted of demersal species. Demersal species included the larvae of Bothidae, Gobiidae, Callionymidae, Sparidae and Serranidae. Gobiidae and Bothidae (Arnoglossus thori and A. laterna) were present throughout the year, with a peak in abundance in September. Dragonets (Callionymus spp.) were also present, with a wide distribution all over the sampling area, in all collections except November with their peak abundance in May and June. Serranidae (Serranus hepatus and S. cabrilla) and Sparidae were present during the warm season, but sporadic catches of Sparidae were also recorded in November and March. Mugilidae, which are benthopelagic species, covered three seasons (September, November, May), indicating that more than one species were included in the samples. Seven coastal epipelagic species were found among the larvae, including the European anchovy, European sardine, round sardinella (Sardinella aurita) Atlantic (Scomber scombrus) and chub (S. japonicus) mackerel, Mediterranean horse mackerel (Trachurus mediterraneus) and the highly migratory bullet tuna (Auxis rochei rochei) (Table 1).
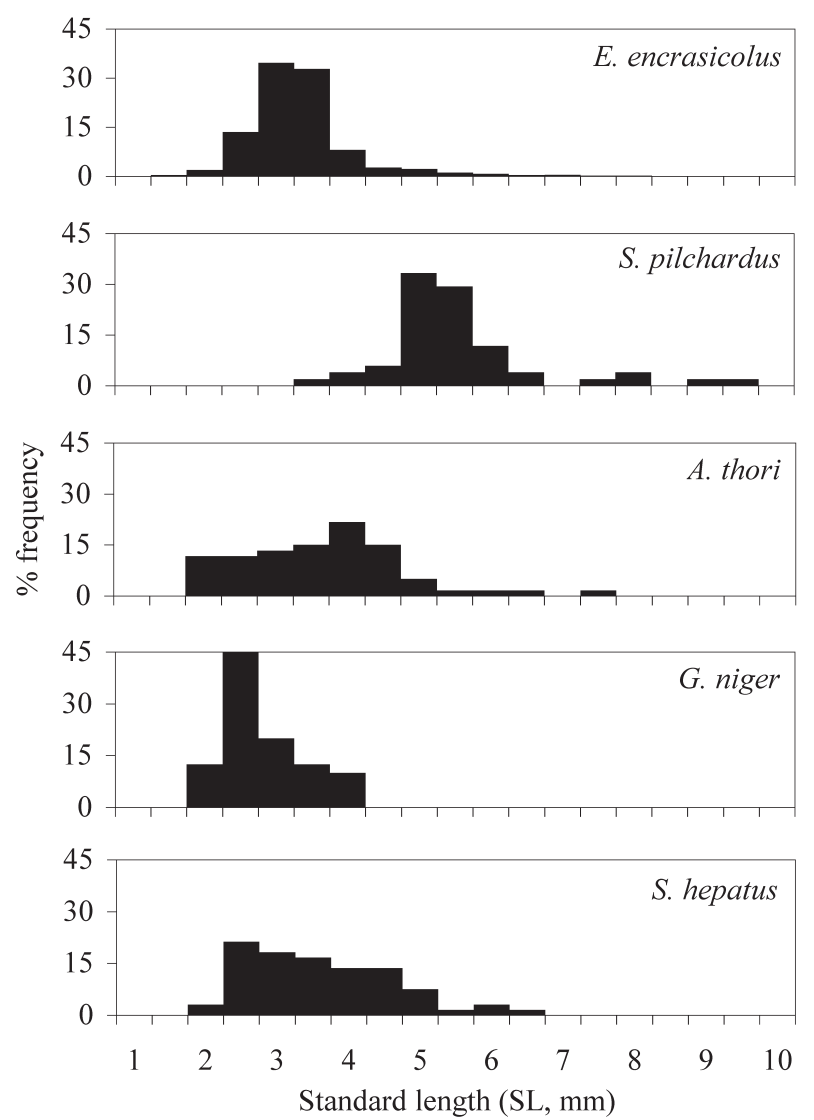

FIG. 3. - Length (SL, $\mathrm{mm}$ ) frequency distribution of the fish larvae of the most abundant species.
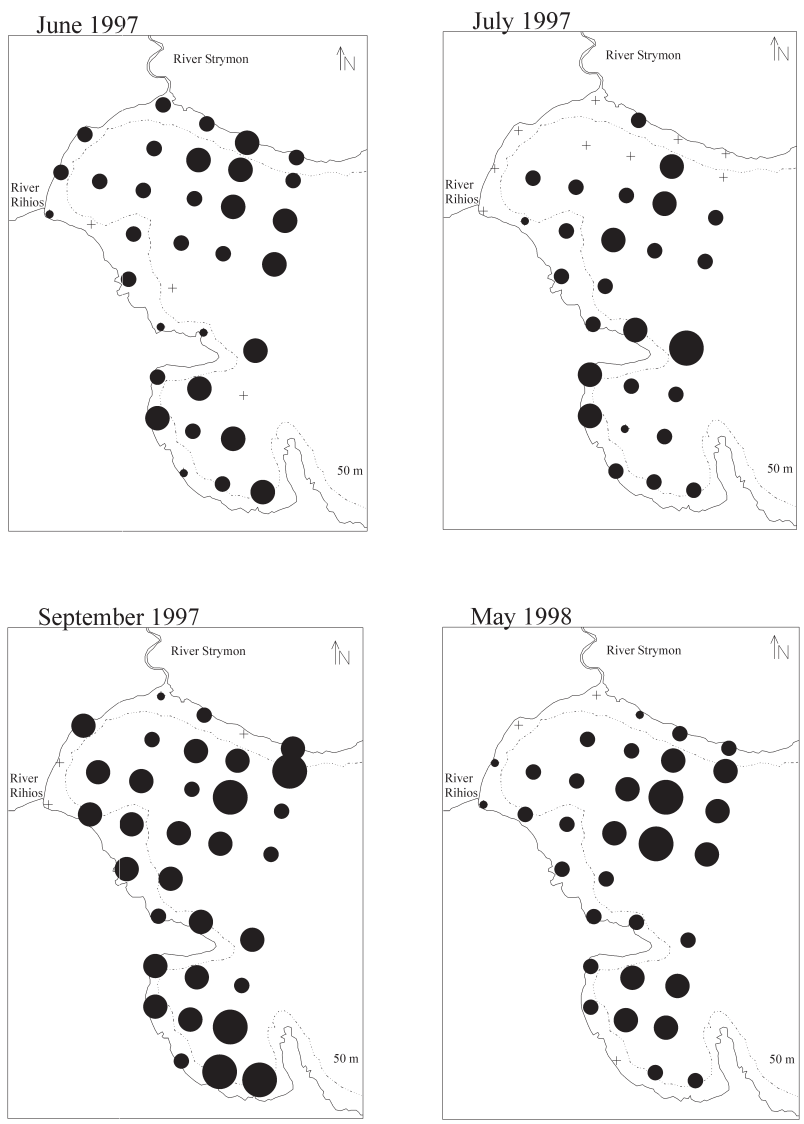

FIG. 4. - Horizontal distribution map of standardised number of larvae $\left(\mathrm{N} / 10 \mathrm{~m}^{2}\right)$ for Engraulis encrasicolus. $(\bullet:$ 1-100, $\bullet$ : 101-1000, : 1001-5000, : 5001-10000)

The round sardinella and the bullet tuna had a very low abundance and a spatially confined presence. The European anchovy and European sardine were the most abundant larvae of epipelagic species. European anchovies were present in high concentrations during the summer months and in very low numbers in November, and were absent in March. Standard larval length frequency distributions (Fig. 3) were compared between nearshore stations (located within a $50 \mathrm{~m}$ contour) and offshore stations (located beyond $50 \mathrm{~m}$ contour) using the KolmogorovSmirnov test (Zar, 1996). Statistically significant differences were recorded $(\mathrm{KS}=7.84, \mathrm{P}<0.001)$, with smaller larvae (mean standard length $=3.04 \mathrm{~mm}$, $\mathrm{n}=708$ ) generally found nearshore, while larger larvae (mean standard length $=3.22 \mathrm{~mm}, \mathrm{n}=2463$ ) were found offshore. European sardine were abundant in November and less abundant in March. The scombrids (Atlantic and horse mackerels and bullet tuna), the Mediterranean horse mackerel and the round sardinella were present during the warm season (May to September). Despite the coastal nature and the shallowness of the study area, larvae of five meso- and 

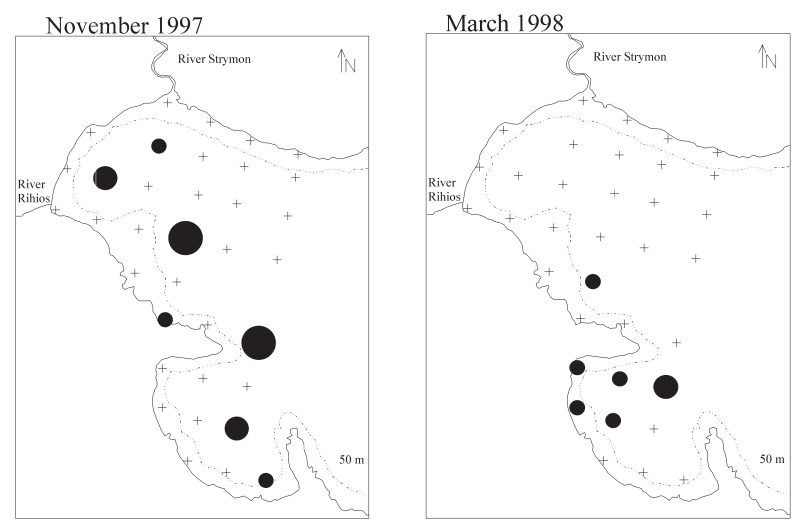

FIG. 5. - Horizontal distribution map of standardised number of larvae $\left(\mathrm{N} / 10 \mathrm{~m}^{2}\right)$ for Sardina pilchardus. (•: 1-100, •: 101-1000, : 1001-5000, : :5001-10000).

bathypelagic species were collected (Ceratoscopelus maderensis, Diaphus holti, Hygophum spp., Lampanyctus crocodilus, Maurolicus muelleri).

The spatial distribution pattern of anchovy larvae (abundance) varied between the four sampling periods (Fig. 4). In June and July 1997, anchovy larvae were found in relatively low concentrations dispersed over the whole sampling area. In September 1997, the highest abundance was observed in the outer Strymonikos Gulf and the eastern Ierissos Gulf. The situation changed during the two following sampling periods. In November 1997 and March 1998 European anchovy larvae were not found. Finally, in May 1998, larvae were concentrated at the centre of the two gulfs towards the open sea. European sardine larvae were only present in November 1997 and March 1998 (Fig. 5). In November 1997, the larvae were sporadically found at stations where the depth was over $50 \mathrm{~m}$, while in March 1998 sardine larvae were concentrated in the

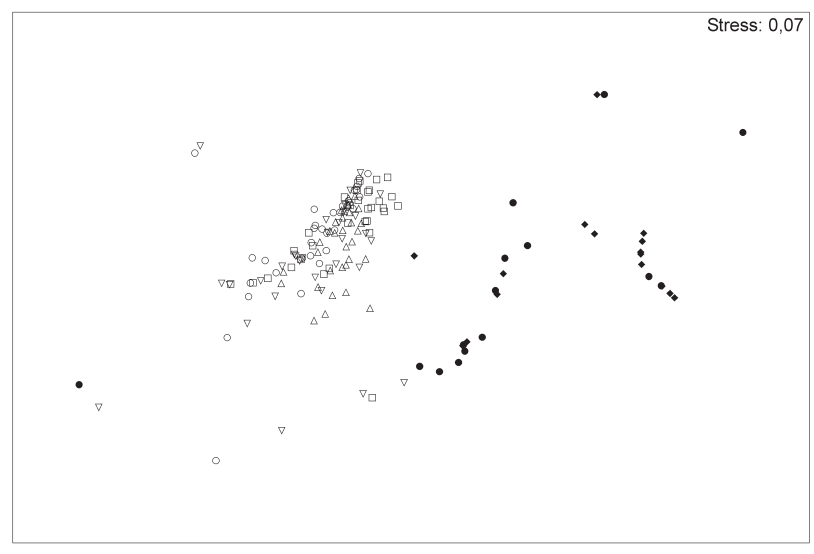

FIG. 6. - Multidimensional scaling showing differences between warm (June, July, September and May) and cold (November and March) season stations in Strymonikos and Ierissos Gulfs ( $\Delta$ : June, $\nabla$ : July, $\square$ : September, $\bullet$ : November, $\bullet$ : March, O: May)
Ierissos Gulf.

Regarding the seasonal patterns, the two-dimensional MDS plot showed a very distinct pattern between the cold season (November and March) and the warm season (June, July, September and May) (Fig. 6). November and March were ordinated to the right of the plot, while the warm months were found in close proximity to the left part of the plot. The analyses of similarity and pairwise comparisons of seasonal assemblages of larval fishes showed that they differed significantly between the warm and the cold months (all $\mathrm{r}$ values were greater than 0.569 , $\mathrm{P}<0.01)$. No significant differences were found within season patterns in the larval community structure (MDS, stress coefficient 0.23; ANOSIM, $\mathrm{r}<0.27, \mathrm{P}>0.1$ for the warm months, MDS, stress coefficient 0.26; ANOSIM, $\mathrm{r}=0.025, \mathrm{P}>0.1$ for the cold months) or in the within monthly comparisons (MDS, stress coefficient $>0.22$ for all months). Moreover, no spatial patterns were identified in the larval community structure between depth zones (MDS, stress coefficient 0.26; ANOSIM, $\mathrm{r}=0.025$, $\mathrm{P}>0.1$ ) and distance from shore (MDS, stress coefficient 0.21 ; ANOSIM, $\mathrm{r}=0.13, \mathrm{P}>0.1$ ), or between the two gulfs (MDS, stress coefficient 0.25; ANOSIM, $r=0.02, P>0.1$ ). Additionally, cluster analyses showed very low similarity between any identified groups in all the above cases.

\section{DISCUSSION}

Membership of the different monthly structures was dynamic, as most taxa occurred in more than one collection and some of them year round. Some taxa were characteristic of particular seasons (e.g. sardine was captured only in November and March), whereas other larvae (e.g. Gobiidae, and Thor's scaldfish, A. thori) were predominant in all seasons. The number of taxa recorded throughout this study is comparable to the 77 taxa previously reported for the entire northern Aegean Sea (Somarakis et al., 2002), despite the limited spatial coverage of the present study. Studies in other Greek marine areas include ninety taxa for Pagasitikos Gulf (central Aegean) (Caragitsou et al., 2001) and sixty-six for Kissamos Gulf (NW Crete) (Papasissi, 1998). Comparison with other Mediterranean studies revealed that most $(55.6 \%)$ of the larval fish taxa found by Sabatés (1990) off the Catalan coast were also present in the Strymonikos Gulf. Similarly, $54.5 \%$ of the taxa recorded by Palomera and Olivar (1996) in 
a nearshore NW Mediterranean area were also present in the Strymonikos Gulf. These results reveal some common ichthyofaunal characteristics of the western and eastern Mediterranean basins.

The size range of larvae caught in the present work did not differ from the ranges previously reported for larvae of the same species caught with bongo nets of different diameter. This is valid for the European anchovy (Olivar and Sabatés, 1997; Somarakis et al., 1998) and the European sardine (Kallianiotis, FRI unpublished data), for which data are available.

Larval abundance, expressed as the standardised number of individuals, exhibited its highest values in September, mainly due to high anchovy abundance. The high anchovy abundance is probably attributed to the high surface temperature (Sylaios et al., 2003) and mesozooplankton abundance (Cladocera, Appendicularia, Chaetognatha and Tunicates) (Michaloudi, 1999) recorded in September 1997, compared to all other months. The same situation was observed in the Pagasitikos Gulf, where the high values of larval abundance in early autumn were also attributed to the high prevailing temperature, as well as to the seasonal peak in phyto- and zoo- plankton abundance (Caragitsou et al., 2001). The highest number of taxa recorded in September has been previously reported for the Pagasitikos Gulf and for the entire Aegean Sea (Caragitsou et al., 1997; Caragitsou et al., 2001). The same authors reported the lowest number of taxa in April and January. The higher number of taxa occurring in the warm season (May, June, July, September) can be attributed to the summer spawners that start their reproduction period during spring/early summer. These include the middlesized pelagics Mediterranean horse mackerel, round sardinella, Atlantic mackerel and bullet tuna and the demersals comber (Serranus cabrilla), greater weever (Trachinus draco) and tonguesole (Symphurus nigrescens). A limited number of species spawn during the winter, including members of the Gadidae family and the European sardine (Caragitsou et al., 1997). Despite the low number of species, the two indices of diversity were higher in March because of the equal allotment of taxa within the sample (Krebs, 1994), which was also exhibited in the evenness values. The increased number of anchovy larvae compared to other species in May resulted in the decrease in both indices. The effect was less evident in September, because more species were collected.
Among the demersal species identified in the present study, Gobiids dominated the community during March, when anchovy and sardine did not spawn. Adult individuals of the early spring spawner black goby (Gobius niger) have been caught in the area (Kallianiotis et al., 1999). The flounders spawn during spring and summer months. Thor's scaldfish (A. thori) adults are usually found at depths of 50-300 m, while the scaldfish (A. laterna) is a more coastal species (Froese and Pauly, 2003). In the present study the scaldfish was only sporadically found at three inshore stations and Thor's scaldfish was very widely distributed, covering almost all stations sampled. The dragonet (Callionymus risso) is the only species of the genus that as an adult was found in the area (Kallianiotis et al., 1999). It is a coastal species, found on sandy bottoms in shallow coastal waters (Froese and Pauly, 2003). Its eggs and larvae are pelagic and this is probably the reason for the wide distribution of the species all over the sampling area. Five out of the seven Mugilidae species that occur in the Aegean Sea were recorded in the estuarine systems of the Strymonikos Gulf. Considering the reproduction period of these species in the area, the mugilid larvae caught in September and November 1997 belong to the summer-autumn spawners (Liza aurata, L. ramada and Mugil cephalus), while the larvae caught in May 1998 probably belong to L. saliens since it is the only species that spawns from late spring (Koutrakis, 2003).

The epipelagic species found in the present study have also been described by Somarakis et al. (2000) in the broader area of the northern Aegean Sea. The European anchovy, round sardinella, chub mackerel, bullet tuna and Mediterranean horse mackerel were widely distributed, particularly over the outer continental shelf. In the present study these species were also found at the coastal stations, except for the bullet tuna, which was only found offshore. The round sardinella is a typical early summer spawner in the northern Aegean Sea. Its occasional presence in the Strymonikos Gulf implies that its spawning in the Strymonikos and Ierissos Gulfs is very limited. Although the majority of species collected were demersal, the larvae of an epipelagic fish (European anchovy) dominated the larval fish collection. Another epipelagic fish (European sardine) was dominant in November. These species are sympatric and competitive at certain stages of their life cycle. To avoid feeding competition, they have specialised in preying on different zooplanktonic organisms 
(Demirhindi, 1961; Tudela and Palomera, 1997). European anchovy and sardine have also evolved different reproductive strategies, since the anchovy spawns from April to October (Palomera, 1992; Garcia and Palomera, 1996; Somarakis et al., 2000), while the sardine spawns between October and March in the northern Aegean Sea (Koutrakis et al., 2001). This explains the dominance of European anchovy larvae in the larval community between May and September and sardine larvae in November. The dominance of small pelagic species (European anchovy and sardine among a few other species) has also been reported for the Pagasitikos Gulf, indicating the importance of enclosed bays as spawning and nursery grounds (Caragitsou et al., 2001). The anchovy has been reported to be the dominant species in terms of larval abundance during the summer in other areas of the Greek seas (Sorra et al., 2000). The high abundance of anchovy larvae, which has also been reported for the northwestern Mediterranean off the Catalan coast (Sabatés, 1990), is probably attributed to the preference of the species to spawn in areas influenced by freshwater input (Palomera, 1992; Tudela and Palomera, 1997). The concentration of European anchovy larvae in the outer parts of the Strymonikos Gulf during May 1998 is probably due to the beginning of the spawning in the outer parts of the gulf (Palomera and Sabates, 1990). The high concentrations recorded in the Ierissos Gulf in September are probably due to the drifting of the larvae due to the southward flow into the Ierissos Gulf that dominates the coastal circulation of the Strymonikos Gulf during the summer (Sylaios et al., 2003). Later in the spawning period, spawning schools disperse to occupy surrounding grounds (Motos et al., 1996). Indeed, the above described pattern of spawning school dispersion and the distribution of anchovy larvae supports the delayed spawning in the coastal areas, which accounts for the smallest size range of European anchovy larvae found nearshore. The spawning concentrations of sardines were more coastal than those of anchovy, a situation also observed in the northwestern Mediterranean Sea (Palomera and Olivar, 1996).

The temporal occurrence of larvae is also influenced by surface water circulation. Although some larvae may stay close to natal areas, oceanographic processes probably influence the larval pattern of presence and abundance in the Strymonikos and Ierissos Gulfs. The samples contained larvae of several meso- and bathypelagic species of Myctophidae
(Ceratoscopelus maderensis, Diaphus holti, Lampanyctus crocodilus, Hygophum spp.) and Sternoptychidae (Maurolicus muelleri). These species as adults typically inhabit mid-waters over the outer continental shelf and slope. After spawning (mainly spring and early summer) their buoyant eggs drift up into food rich waters near the thermocline where the embryos hatch. The drifting into the Strymonikos Gulf is probably attributed to the more saline Levantine Intermediate Water that originates in the Levantine Sea (eastern Mediterranean) and propagates through the southern Aegean, and that during the summer months enters the deeper parts of the outer gulf (Sylaios et al., 2003). Four out of the five bathypelagic species were found during June and all of them were collected offshore (beyond the $50 \mathrm{~m}$ contour). The presence of meso- and bathypelagic larvae observed in the Strymonikos Gulf has also been reported for coastal areas of the western Mediterranean (Sabatés and Olivar, 1996, Palomera and Olivar, 1996).

Non-metric multidimensional scaling revealed the importance of seasonality in community structure. Even if seasonality can be related to different parameters, a biological factor is believed to play a crucial role. The separation of two distinct seasons was determined by the reproductive strategy of the two dominant pelagic species: the extensive reproductive period of the European anchovy and its dominance during the warm months and the dominance of sardine and Gobiidae in the cold season. Small pelagic fish have been reported to act as dominant species and have a significant role in shaping the structure of the marine ecosystems (Cury et al., 2000). The absence of spatial patterns in the larval fish community structure suggests that only one association of fish larvae can be considered in the study area, at least during the study period. This is probably due to the shallowness of the area, the horizontal temperature and salinity homogeneity that prevails in the Strymonikos and Ierissos Gulfs and the limited contribution of river inputs in all seasons but especially during the summer months, as was pointed out by Sylaios et al. (2003). These results are supported by most of the authors who have worked in the Mediterranean. Somarakis et al. (2002) reported that depth was the most important determinant of taxonomic composition and abundance and included the Strymonikos and Ierisssos Gulfs in the areas characterised by the coastal assemblage, like most of the coastal zone of the northern Aegean Sea. The depth-related separation 
of assemblages is also pointed out in the northwestern Mediterranean (off the Catalan coast) by Sabatés (1990), who described a gradual "inshore-offshore" separation over the $200 \mathrm{~m}$ depth contour rather than well-defined associations. Sabatés and Olivar (1996) found three groups that gradually cover the area over the $1000 \mathrm{~m}$ depth contour. The first group consists of the coastal stations (close to the $200 \mathrm{~m}$ depth contour), the second of the stations over the shelf and the shelf slope, and the third of the stations over the $1000 \mathrm{~m}$ contour.

Sabatés (1990) highlights the importance of seasonality in the community structure. Palomera and Olivar (1996) also outline the importance of seasonality in the coastal zone, which is reflected in a higher number of species during the spring and summer months but higher total larval abundance in winter. This was attributed to the reproductive strategy of two species and was reflected in the high presence of the European sardine and the sand eel Gymnamodytes semisquamatus. In the present study, both the standardised number of larvae (due to the presence of the European anchovy) and the number of taxa were higher during the warm period (September and June), but the two indices of diversity and the mean evenness was higher during the cold period (March). In other coastal areas (NE Pacific coast), where environmental instability is higher, seasonality has also been reported to be an important factor contributing to the general distribution patterns of larval fish communities (e.g. Richardson et al., 1980).

In conclusion, seasonality is an important parameter determining the larval fish community structure in Strymonikos Gulf. This shows the importance of ichthyoplankton sampling over a yearly cycle, at least for the coastal larval fish studies. Moreover, the absence of well-defined larval fish associations revealed the importance of depth in the identification of different spatial patterns in an area. The present work confirmed the presence of mesoand bathypelagic species in areas where depth is too shallow for adults, and indicates the influence of deeper water mass intrusion.

\section{ACKNOWLEDGEMENTS}

The study is part of a EU co-funded LIFE project entitled "Concerted actions for the management of the Strymonikos coastal zone" and was carried out by the Fisheries Research Institute of Kavala,
Greece. The authors would like to thank Ms Fotini Kallianioti for identifying the larvae, Drs Isabel Palomera and M. Pilar Olivar for their helpful comments on an earlier version of the manuscript, and two anonymous referees whose comments resulted in a substantial improvement of the manuscript.

\section{REFERENCES}

Barbopoulos, K.A., V.H. Kourafalou and Y.N. Krestenitis. - 2000. Three-dimensional numerical modeling of North Aegean Sea circulation. Proc. $6^{\text {th }}$ Hell. Symp. Ocean. Fish., I: 145-149.

Bethoux, J.P. - 1980. Mean water fluxes across sections in the Mediterranean Sea, evaluated on the basis of water and salt budgets and of observed salinities. Oceanol. Acta, 3: 79-88.

Caragitsou, E., A. Siapatis, A. Anastasopoulou and C. Papaconstantinou. - 1997. Seasonal distribution of ichthyoplankton in the Aegean Sea. Proc. $5^{\text {th }}$ Hell. Symp. Ocean. Fish., II: 143-145.

Caragitsou, E., A. Siapatis and A. Anastasopoulou. - 2001. Seasonal structure of fish larvae assemblages in the Pagasitikos Gulf (Greece). Rapp. Comm. Int. Mer. Médit., 36: 250.

Clarke, K.R. and R.M. Warwick. - 1994. Change in marine communities: an approach to statistical analysis and interpretation. Natural Environment Research Council, Plymouth Marine Laboratory, Plymouth.

Clarke, K.R. and R.N. Gorley. - 2001. Primer v5: User Manual/Tutorial, Plymouth.

Demirhindi, U. - 1961. Nutrition of the sardine (Sardina pilchardus Walb.). Proc. Gen. Fish. Counc. Medit., 6: 253-259.

Cury, P., A. Bakun, R.J.M. Crawford, A. Jarre, R.A. Quinones, L.J. Shannon, and H.M. Verheye. - 2000. Small pelagics in upwelling systems: patterns of interaction and structural changes in "wasp-waist" ecosystems. ICES J. Mar. Sci., 57: 603-618.

Doyle, M.J., W.W. Morse and A.W. Kendall. 1993. A comparison of larval fish assemblages in the temperate zone of the northeast Pacific and northwest Atlantic oceans. Bull. Mar. Sci., 53: 588644.

Froese, R. and D. Pauly. - 2003. FishBase. World Wide Web electronic publication. www.fishbase.org, 25 July, 2003.

Ganias, K., S. Somarakis, C. Koutsikopoulos, E. Caragitsou, A. Machias, N. Tsimenides and A. Theodorou. - 2000. Oceanographic, ichthyoplanktonic and biological study of the reproduction of sardine off the central Hellenic coasts. Greek Fish. News, 233: 41-48. (in Greek).

Garcia, A. and I. Palomera. - 1996. Anchovy early life history and its relation to its surrounding environment in the western Mediterranean basin. Sci. Mar., 60(Suppl. 2): 155-166.

Hatzigiannakis, S. - 1999. Hydrology of Strymonikos Gulf watershed. In: E. Koutrakis and E. Lazaridou (eds.), Description of the coastal zone of Strymonikos and Ierissos Gulfs, pp. 5-33. Final Technical Report (in Greek, English abstract).

Kallianiotis, A. - 1996. The anchovy fishery in the Aegean Sea. A flourishing industry or a lost affair? Sci. Mar., 60(Suppl. 2): 287-288.

Kallianiotis, A., K. Sophronidis and P. Vidoris. - 1999. Analysis of fish fauna in the Strymonikos and Ierissos Gulfs using a bottom trawl. In: E. Koutrakis and E. Lazaridou (eds.), Description of the coastal zone of Strymonikos and Ierissos Gulfs, pp. 405456. Final Technical Report (in Greek, English abstract).

Kaloumenos, L. - 1984. Hydrologic characteristics of the area Strymonikos Gulf-Athos Peninsula-Kavala Gulf. Proc. $1^{\text {st }} \mathrm{Hell}$. Symp. Ocean. Fish., 32-37.

Koutrakis, E. - 2003. Temporal distribution of grey mullet fry (Mugilidae) in the estuarine systems of Strymonikos Gulf (Greece). J. Appl. Ichthyol. (in press).

Koutrakis, E., A. Tsikliras and N. Kamidis. - 2001. On the biology of sardine Sardina pilchardus (Walbaum, 1792) in the Gulf of Kavala. Proc. 10 th Hell. Icthyol. Conf., 69-72.

Krebs, C.J. - 1994. Ecology: The experimental analysis of distribution and abundance. Harper and Row Publishers, New York.

Magurran, A.E. - 1988. Ecological diversity and its measurement. GroomHelm, London. 
Malanotte-Rizzoli, P. and A. Hecht. - 1988. Large-scale properties of the Eastern Mediterranean: a review. Oceanol. Acta, 11: $323-335$

Mertzanis, C. - 1994. Study of flooding waves at Strymon River. MSc. thesis, Univ. of Thessaloniki (in Greek, English abstract)

Michaloudi, E. - 1999. Mesozooplankton in the Strymonikos and Ierissos Gulfs. In: E. Koutrakis and E. Lazaridou (eds.), Description of the coastal zone of Strymonikos and Ierissos Gulfs, pp. 441-453. Final Technical Report (in Greek, English abstract).

Moser, H.G. and P.E. Smith. - 1993. Larval fish assemblages and oceanic boundaries. Bull. Mar. Sci., 53: 283-289.

Motos, L., A. Uriarte and V. Valencia. - 1996. The spawning environment of Bay of Biscay anchovy (Engraulis encrasicolus L.). Sci. Mar., 60(Suppl. 2): 117-140.

Nonaka, R.H., Y. Matsuura and K. Suzuki. - 2000. Seasonal variation in larval fish assemblages in relation to oceanographic conditions in the Abrolhos Bank region off eastern Brazil. Fish. Bull., 98: 767-784.

Olivar, M.P. and A. Sabatés. - 1997. Vertical distribution of fish larvae in the north-west Mediterranean Sea in spring. Mar. Biol., 129: 289-300.

Palomera, I. - 1992. Spawning of anchovy Engraulis encrasicolus in the Northwestern Mediterranean relative to hydrographic features in the region. Mar. Ecol. Prog. Ser., 79: 215-223.

Palomera, I. and A. Sabatés. - 1990. Co-occurrence of Engraulis encrasicolus and Sardinella aurita eggs and larvae in the northwestern Mediterranean. Sci. Mar., 54: 61-67.

Palomera, I. and M.P. Olivar. - 1996. Nearshore ichthyoplankton off the Costa Brava (northwest Mediterranean Sea). Publ. Espec. Inst. Esp. Oceanogr., 22: 71-75.

Papasissi, C. - 1998. Contribution to ichthyoplankton ecology in the Gulf of Kissamos (NW Crete). PhD thesis, Univ. Patra (in Greek, English abstract).

Richardson, S.L., J.L. Laroche and M.D. Richardson. - 1980. Larval fish assemblages and associations in the north-east Pacific coast along the Oregon coast, winter-spring 1972-1975. Estuar. coast. Mar. Sci., 11: 671-699.

Sabatés, A. - 1990. Distribution pattern of larval fish populations in the Northwestern Mediterranean. Mar. Ecol. Prog. Ser., 59: $75-82$

Sabatés, A. and M.P. Olivar. - 1996. Variation of larval fish distributions associated with variability in the location of a shelfslope front. Mar. Ecol. Prog. Ser.,135: 11-20.

Somarakis, S., B. Catalano and N. Tsimenides. - 1998. Catchability and retention of larval European anchovy, Engraulis encrasicolus, with bongo nets. Fish. Bull., 96: 917-925.

Somarakis, S., E. Maraveya and N. Tsimenides. - 2000. Multispecies ichthyoplankton associations in epipelagic species: is there any intrinsic adaptive function? Belg. J. Zool., 130 (Suppl.): 129-133.

Somarakis, S., P. Drakopoulos and V. Filippou. - 2002. Distribution and abundance of larval fish in the northern Aegean Sea -eastern Mediterranean- in relation to early summer oceanographic conditions. J. Plankton Res., 24(4): 339-357.

Sorra, V., C. Koutsikopoulos, N. Fragopoulou and I. Lykakis. 2000. Distribution of fish larvae in Patraikos Gulf and Gulf of Nafpaktos. Proc. $9^{\text {th }}$ Ichthyol. Congr. 81-85.

Stamatis N., D. Ioannidou and E. Koutrakis. - 2001. Monitoring of key eutrophication parameters at three inshore stations of Strymonikos Gulf, north Aegean Sea. Fresenius Envir. Bull., 10(9): 706-710.

Sylaios, G., E. Koutrakis and A. Kallianiotis. - 2003. Hydrographic variability, nutrient distribution and water mass dynamics in Strymonikos Gulf (N. Greece). Oceanol. Acta (in press).

Tudela, S. and I. Palomera. - 1997. Trophic ecology of the European anchovy Engraulis encrasicolus in the Catalan Sea (northwest Mediterranean). Mar. Ecol. Prog. Ser., 160: 121-134.

Zar, J.H. -1999 . Biostatistical Analysis, $4^{\text {th }}$ edition, Prentice-Hall, New Jersey.

Scient. ed.: J.J. Govoni 
